\title{
Relationship between bill morphology and preening behaviour in waders
}

\author{
ANDRES BARBosa \\ Departamento de Ecología Evolutiva, Museo Nacional de Ciencias Naturales, CSIC, \\ c/ José Gutiérrez Abascal 2, 28006 Madrid, Spain
}

Received 19 December 1994, accepted 15 January 1996

\begin{abstract}
The relationship between bill morphology and preening behaviour was studied in 11 species of waders. On the assumption that species with long bills might be less efficient at preening than birds with short bills, the hypothesis was tested that long-billed species devoted more time to preening than short-billed species. Results showed a positive relationship between bill length and time spent preening, supporting the hypothesis. However, bill width, bill depth and curvature were not related to preening behaviour.
\end{abstract}

KEY WORDS: preening, bill morphology, waders.

\section{INTRODUCTION}

The literature concerning the functional significance of bird bills is abundant. Authors have found relationships between bill morphology (length, width and depth) and diet (HespenheIde 1973, Grant 1986), prey size (NEWTON 1967, ZwarTs 1980), prey mobility (BEECHER 1962, LEDERER 1975), feeding techniques (BocK 1966, CARRASCAL et al. 1990, KeAst \& SAUnders 1991), and microhabitat use (AsHMOLE 1970, HARRINGTON 1982).

Bills are also important tools for preening (i.e. touching the plumage with the bill to groom). Efficient preening is essential for the straightening and oiling of feathers as well as for the removal of dirt from the body surface (Simmons 1985). Preening is also important for defence against ectoparasites. Inefficient preening results in a rapid increase in ectoparasite load (BROWN 1972, 1974; CLAYTON 1991), which reduces survival (CLAYTON 1989) and mating success (CLAYTON 1990).

In spite of the importance of preening, little attention has been paid to the functional significance of the bill for preening. Recently, Clayton \& Cotgreave (1994) investigated the functional value of bill-related grooming behaviour. On the assumption that species with long bills might be less efficient at preening than birds with short bills, and that there are no differences in parasite load between species (Clayton \& Cotgreave 1994). These authors therefore suggested that other 
behaviours such as scratching (i.e. touching the plumage with the foot) could compensate for inefficient preening, and they found a positive correlation between the proportion of grooming time spent scratching and bill length. Other compensatory behaviours might also be displayed by birds. I tested the hypothesis that long-billed species simply devote more time to preening than short-billed species. Relationships between preening and other bill characteristics such as width, depth and curvature, which would have important mechanical consequences for handling objects (LEDERER 1975), were also analyzed.

Waders show great diversity in bill morphology (BARBOSA 1991, 1994), making them a good group to test the proposed hypothesis.

\section{MATERIALS AND METHODS}

I observed the preening behaviour of 11 wader species (Table 1) foraging at the Natural Park of Delta del Ebro (NE Spain). All observations were made between November and April 1990-1992, using binoculars and a 40-60 $\times$ spotting scope. Waders have their highest rate of mortality in winter (Goss-CusTARD et al. 1977) and food shortage seems to be involved (GossCUSTARD 1980). Therefore, they spend a very high proportion of their time feeding in winter (Goss-CustaRD et al. 1977). From optimal considerations, this would place a restriction on time available for preening. Therefore, the analyses will be based on a restricted situation making the results more valuable than when preening is analyzed in a resting situation. Focal birds were randomly chosen during regular surveys of the study area. To avoid problems of pseudoreplication (HULBERT 1984), individuals were sampled only once. As birds were not colour-marked, I sampled a small proportion of birds in each flock to ensure they were different individuals (i.e. in a flock of about 100 individuals, I sampled 5-10 birds from the upper side, 5-10 birds from the lower side, 5-10 birds from the left side, and 5-10 birds from the right side of the flock). Each of the birds sampled was at least $20 \mathrm{~m}$ from the previous bird

Table 1.

Bill morphological and preening data.

\begin{tabular}{|c|c|c|c|c|c|c|c|c|c|c|c|c|}
\hline \multirow{2}{*}{ Species } & \multicolumn{3}{|c|}{ Bill length } & \multicolumn{3}{|c|}{ Bill depth } & \multicolumn{3}{|c|}{ Bill width } & \multicolumn{3}{|c|}{$\begin{array}{l}\% \text { time spent } \\
\text { preening }\end{array}$} \\
\hline & $\mathrm{n}$ & $\overline{\mathrm{x}}$ & SE & $\mathrm{n}$ & $\overline{\mathrm{x}}$ & SE & $\mathrm{n}$ & $\overline{\mathrm{x}}$ & SE & $\mathrm{n}$ & $\overline{\mathrm{x}}$ & $\mathrm{SE}$ \\
\hline Vanellus vanellus & 40 & 32.91 & 1.21 & 16 & 6.57 & 0.50 & 43 & 8.14 & 0.59 & 39 & 0.01 & 0.01 \\
\hline Charadrius alexandrinus & 9 & 23.33 & 0.79 & 7 & 3.82 & 0.19 & 9 & 5.43 & 0.29 & 31 & 0.12 & 0.10 \\
\hline Pluvialis squatarola & 21 & 35.23 & 1.67 & 17 & 6.55 & 0.55 & 20 & 8.32 & 0.62 & 35 & 0.06 & 0.05 \\
\hline Haematopus ostralegus & 13 & 75.68 & 5.54 & 17 & 8.98 & 0.87 & 17 & 13.2 & 0.87 & 8 & 3.63 & 1.90 \\
\hline Himantopus himantopus & 6 & 71.01 & 4.21 & 5 & 4.33 & 0.12 & 8 & 7.69 & 0.39 & 25 & 2.54 & 1.21 \\
\hline Recurvirostra avosetta & 5 & 80.79 & 8.10 & 3 & 4.87 & 0.20 & 6 & 10.2 & 0.41 & 51 & 1.48 & 0.22 \\
\hline Limosa limosa & 8 & 109.2 & 5.29 & 4 & 9.18 & 0.29 & 7 & 9.60 & 0.53 & 63 & 0.13 & 0.07 \\
\hline Limosa lapponica & 12 & 92.561 & 13.6 & 14 & 8.29 & 0.71 & 15 & 9.51 & 0.65 & 10 & 0.38 & 0.23 \\
\hline Tringa totanus & 23 & 49.36 & 2.96 & 16 & 4.56 & 0.32 & 23 & 6.41 & 0.59 & 29 & 0.27 & 0.16 \\
\hline Tringa erythropus & 6 & 66.19 & 3.30 & 6 & 4.80 & 1.32 & 9 & 6.83 & 0.52 & 10 & 6.06 & 2.98 \\
\hline Calidris alpina & 38 & 38.45 & 2.77 & 26 & 4.96 & 0.30 & 42 & 5.23 & 0.56 & 116 & 1.67 & 0.37 \\
\hline
\end{tabular}

n (sample size), $\bar{x}$ (mean), SE (standard error). 
sampled. This procedure assures probabilistically that different individuals were sampled (see BARBOSA 1995). Activities during foraging including preening were tape-recorded for a $2 \mathrm{~min}$ period on average, and percentage of time spent preening was subsequently calculated using Observer 6.0 software. The study was carried out between the post-breeding moult period and the pre-breeding moult period for all species, therefore variables such as moult schedules of individual species do not affect the results. To avoid over- or under-estimation of time spent preening through inclusion or exclusion of the preferred preening time of individual species, all birds were, I sampled throughout the daylight hours.

Bill morphology (length, depth, and width) was measured with digital calipers to the nearest $0.01 \mathrm{~mm}$ from skulls belonging to several museum collections (Cátedra de Vertebrados, Facultad de Biología, Universidad Complutense de Madrid; Museo Nacional de Ciencias Naturales, CSIC, Madrid; Institut d'Estudis Avançats de les Illes Balears, CSIC, Palma de Mallorca; Laboratorio de Arqueozoología, Facultad de Ciencias, Universidad Autónoma de Madrid; Museo de Ciencias Naturales de Tenerife; British Museum Natural History, Subdpt. Ornithology, Tring; Zoologisk Museum, Copenhagen; Institut für Haustierkunde, Kiel; Zoologisches Forschungsinstitut und Museum Alexander König, Bonn; Institut Royal des Sciences Naturelles de Belgique, Bruxelles). Size-corrected lengths were obtained by dividing each variable by the cube root of body weight (LEISLER \& WinKLER 1985). Mean body weight data were obtained from CRAMP (1983).

Organisms are related hierarchically, and therefore, data for different species are not statistically independent (Grafen 1989, Harvey \& Pagel 1991). To control for non-independence of taxa in comparative analysis, I used the phylogenetically independent contrasts analysis (FELSENSTEIN 1985, 1988). Phenotypic data for the tip species of any monophyletic group can be transformed into N-1 independent contrasts. These contrasts are calculated as the value of a trait at one tip (or node) of a phylogeny substracted from the value of its sister tip or node. Thus each species or node is compared to its closest included relative. If characters have evolved by independent Brownian motion, the contrast are statistically independent (see Harvey \& Pagel 1991, Martins \& Garland 1991, Garland et al. 1992 for more details). Felsenstein's method requires complete knowledge of both phylogenetic relationships among spe-

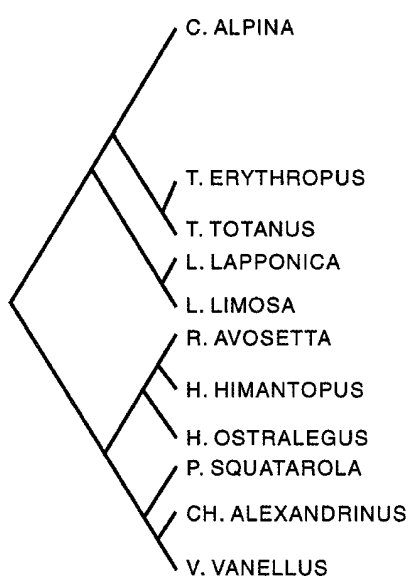

Fig. 1. - Phylogenetic relationships of the waders species used in the analyses (based on Sibley \& AHLQuist 1990).

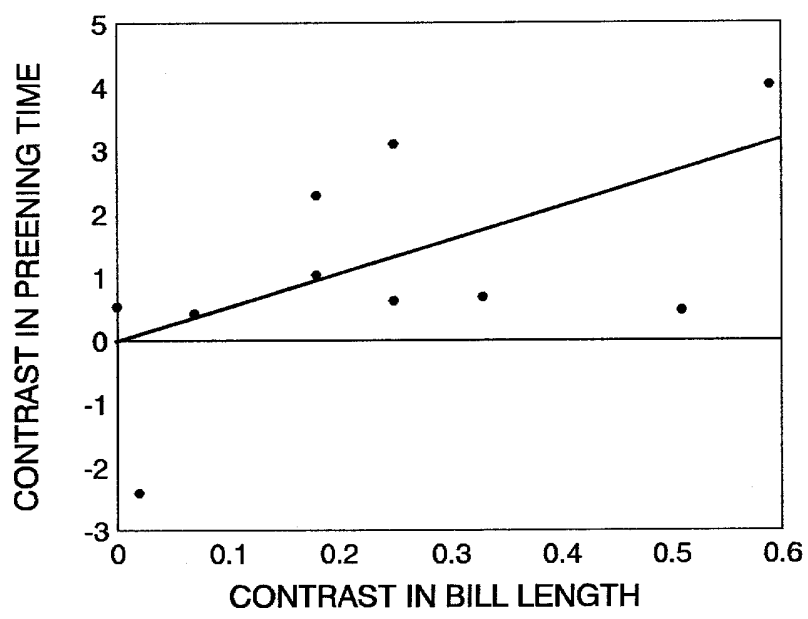

Fig. 2. - Bill length contrasts vs preening time contrasts. 
cies and branch lengths (in units of expected variance of character change). I used phylogenetic information (Fig. 1) from Sibley \& Ahlouist (1990). Mean value of bill length, depth and width and percentage of time spent preening (Table 1) were used to calculate the contrasts. As the direction of substraction in each contrast is arbitrary, regression through the origin (GARLAND et al. 1992) was used to test the relationship between bill morphology and preening. To make unique representations of bivariate scatterplot, one must set all contrasts for one trait (e.g. the independent variable) to positive, while switching signs for the other trait's corresponding contrasts. Regression through the origin yields the same results whether contrasts are thus positivized or not (GARLAND et al. 1992). Differences between time spent preening by a species with a curved bill (Recurvirostra avosetta) and the other species with straight bills, were test by means of Wilcoxon ranks test. All data were log-transformed prior to the analyses.

\section{RESULTS}

The analysis showed a positive relationship between bill length and time spent preening $(\mathrm{r}=0.55 P=0.02$ one-tailed $\mathrm{n}=10$; Fig. 2$)$. However, no significant relationship $(r=0.12 P>0.05$ and $r=-0.31 P>0.05$ two-tailed $)$ was found between the other variables of bill morphology (width and depth respectively) and the time spent preening by waders. No differences were found between time spent preening in curve-billed species and straigh-billed species $(Z=0.94 P>0.05)$.

\section{DISCUSSION}

The results support the hypothesis that long-billed species spend more time preening during bouts of foraging than short-billed species. ClaYTON \& Cotgreave (1994) analyzed grooming of the whole body, including the breast and neck. To groom the breast and neck, which can be inaccessible to long-billed species, birds must scratch, that is, touch their plumage with the foot. I have no data on scratching behaviour, so my study is limited to the body regions accessible by the bill. This fact does not allow a strict comparison of the two studies. Nevertheless, my results could be considered complementary to CLAYTON \& CotgREAVE's. It suggests a relative lack of preening dexterity in long-billed species which could lead them to spend more time preening than short-billed species during stress conditions such as foraging in winter.

Clayton \& Cotgreave (1994) pointed out the necessity of studying the relationships between bill characteristics other than length, (i.e. bill depth, width and curvature) and preening behaviour. I found no relation between these bill characters and preening behaviour. Functional significance of both bill depth and width are related to the handling of prey (e.g. LEDERER 1975). Neither oiling nor removal of ectoparasites seem to have the mechanical requirements imposed by prey (mobility, size, etc.), as ectoparasites are much smaller than wader prey and have less mobility. Therefore, it is expected that bill width and depth do not correlate with preening behaviour. On the other hand, neither did bill curvature show a relationship with preening, as the only species with such character, Recurvirostra avosetta, did not differed in time spent preening from the other species. These results reinforce the functional importance of bill length in preening behaviour. 


\section{ACKNOWLEDGEMENTS}

I thank the curators of the collections used, the Agricultural and Fish Department of the Catalonian Generalitat and the Natural Park of Delta del Ebro facilities for allowing to conduct this study. Financial support was provided by a CSIC-CAM grant, British Council grant-in-aid and CajaMadrid. R. Garcia-Perea corrected the language. This study is a contribution to the DGICYT project PB0870389.

\section{REFERENCES}

Ashmole M.J. 1970. Feeding of western and semipalmated sandpipers in Peruvian winter quarters. Auk 87: 131-135.

BARBosa A. 1991. European waders identification key on the basis of the cranial morphology. Ardeola 38: 249-263.

BARbosa A. 1994. Estudio ecomorfológico de las aves limícolas (Aves: Charadrii): modificaciones adaptativas relacionadas con la búsqueda del alimento. Ph.D. Thesis, Universidad Complutense, Madrid.

BARBosa A. 1995. Foraging strategies and their influence on scanning and flocking behaviour of waders. Journal of Avian Biology 26: 182-186.

BEECHER W.J. 1962. The biomechanics of the bird skull. Bulletin of the Chicago Academy of Sciences 11: 10-33.

Bock W.J. 1966. An approach to the functional analysis of bill shape. Auk 83: 10-51.

BROWN N.S. 1972. The effect of host beak condition on the size of Menacanthus stramineus populations of domestic chicken. Poultry Science 51: 162-164.

BRown N.S. 1974. The effect of louse infestation, wet feathers, and relative humidity on the grooming behavior of the domestic chicken. Poultry Science 53: 1717-1719.

Carrascal L.M., Moreno E. \& Telleria J.L. 1990. Ecomorphological relationships in a group of insectivorous birds of temperate forests in winter. Holartic Ecology 13: 105-111.

Clayton D.H. 1989. Coevolutionary ecology of the rock dove (Columba liva) and its chewing lice (Insecta: Mallophaga). Ph.D. Thesis, University of Chicago.

Clayton D.H. 1990. Mate choice in experimentally parasitized rock doves: lousy males lose. American Zoologist 30: 251-262.

Clayton D.H. 1991. Coevolution of avian grooming and ectoparasite avoidance, pp. 258-289. In: Loye J.E \& Zuk M., Edits. Bird-parasite interactions: ecology, evolution and behavior. Oxford: Oxford University Press.

Clayton D.H. \& Cotgreave P. 1994. Relationship of bill morphology to grooming behaviour in birds. Animal Behaviour 47: 195-201.

CRAMP S. 1983. Handbook of birds of Europe the Middle East and North Africa. Vol. III, Waders to Gulls. Oxford: Oxford University Press.

Felsenstein J. 1985. Phylogenies and the comparative method. American Naturalist 125: 1-15.

Felsenstein J. 1988. Phylogenies and quantitative characters. Annual Review of Ecology and Systematics 19: 445-471.

Garland T., HaRVey P.H. \& Ives A.R. 1992. Procedures for the analysis of comparative data using phylogenetically independent contrasts. Systematic Biology 41: 18-32.

Goss-CustaRd J.D. 1980. Competition for food and interference among waders. Ardea 68: 31-52.

Goss-Custard J.D., Jenyon R.A., Jones R.E., Newberry P.E. \& Willians R. Le B. 1977. The ecology of the Wash. II Seasonal variation in the feeding conditions of wading birds (Charadrii). Journal of Applied Ecology 14: 701-719.

Grafen A. 1989. The phylogenetic regression. Philosophical Transactions of the Royal Society of London (B, Biological Sciences) 326: 119-157.

Grant P.R. 1986. Ecology and evolution of Darwin's finches. Princeton, New Jersey: Princeton University Press. 
HARRINGTON B.A. 1982. Morphometric variation and habitat use of semipalmated sandpipers during a migratory stopover. Journal of Field Ornithology 53: 258-262.

HaRvey P.H. \& Pagel M.D. 1991. The comparative method in evolutionary biology. Oxford: Oxford University Press.

HeSPENHEIDE H.A. 1973. Ecological inferences from morphological data. Annual Review of Ecology and Systematics 4: 213-229.

Hulbert S.H. 1984. Pseudoreplication and the design of ecological field experiments. Ecological Monographs 54: 187-211.

KeAST A. \& SAUNDERS S. 1991. Ecomorphology of the North American Ruby-crowned (Regulus calendula) and Golden-crowned (R. satrapa) kinglets. Auk 108: 880-888.

LEDERER R.J. 1975. Bill size, food size and jaw forces of insectivorous birds. Auk 92: 385-387.

LeIsLER B. \& WinKLER H. 1985. Ecomorphology, pp. 155-186. In: Johnston R.F., Edit. Current ornithology. Vol. 2. New York: Plenum Press.

Martins E.P. \& Garland T. 1991. Phylogenetic analyses of the correlated evolution of continuous characters: a simulation study. Evolution 45: 534-557.

Newton I. 1967. The adaptive radiation and feeding ecology of some British finches. Ibis 109: 33-98.

Sibley C.G. \& Ahlouist J.E. 1990. Phylogeny and classification of birds. A study of molecular evolution. New York: Yale University Press.

Simmons K.E.L. 1985. Anting: comfort behaviour; dusting; sunning, pp. 101-104. In: Campbell B. \& Lack E., Edits. A dictionary of birds. Vermillion, South Dakota: Buteo Books.

ZWARTS L. 1980. Intra- and interspecific competition for space in estuarine bird species in a one-prey situation, pp. 1045-1050. In: Wiens J. \& Newton J., Edits. Symposium on resource utilization, competition and avian community structure. Actis XVII Congressus Internationalis Ornithologici. Berlin: Deutsche Ornithologen-Gesellschaft. 